Babelyuk Valeriy Y., Tserkovnyuk Ruslan G., Ruzhylo Sofiya V., Dubkova Galyna I., Babelyuk Nazariy V., Zukow Walery, Popovych Igor $\mathbf{L}$. Causal relationships between the parameters of gas discharge visualization and leukocytogram. Journal of Education, Health and Sport. 2021;11(7):258-269. eISSN 2391-8306. DOI http://dx.doi.org/10.12775/JEHS.2021.11.07.024 https://apcz.umk.pl/czasopisma/index.php/JEHS/article/view/JEHS.2021.11.07.024

This article is published with open access at Licensee Open Journal Systems of Nicolaus Copernicus University in Torun, PolandOpen Access. This article is distributed under the terms of the Creative Commons Attribution Noncommercial License which permits any noncommercial use, distribution, and reproduction in any medium,provided the original author (s) and source are credited. This is an open access article licensed under the terms of the Creative Commons Attribution Non commercial license Share alike. (http://ereation the work is properly cited.The authors declare that there is no conflict of interests regarding the publication of this paper.

Received: 10.07.2021. Revised: 20.07.2021. Accepted: 30.07.2021.

\title{
CAUSAL RELATIONSHIPS BETWEEN THE PARAMETERS OF GAS DISCHARGE VISUALIZATION AND LEUKOCYTOGRAM
}

\author{
Valeriy Y. Babelyuk ${ }^{1,2}$, Ruslan G. Tserkovnyuk ${ }^{1}$, Sofiya V. Ruzhylo ${ }^{3}$, \\ Galyna I. Dubkova ${ }^{2}$, Nazariy V. Babelyuk ${ }^{1,2}$, Walery Zukow ${ }^{4}$, Igor L. Popovych ${ }^{1,5}$ \\ ${ }^{1}$ Ukrainian Scientific Research Institute of Medicine for Transport MHU, Odesa, \\ Ukraine valeriybabelyk64@gmail.com \\ ${ }^{2}$ Clinical Sanatorium „Moldova”, Truskavets', Ukraine dubkovahalyna@gmasil.com \\ ${ }^{3}$ Ivan Franko Pedagogical University, Drohobych, Ukraine doctor-0701@ukr.net \\ ${ }^{4}$ Nicolaus Copernicus University, Torun, Poland w.zukow@wp.pl \\ ${ }^{5}$ OO Bohomolets' Institute of Physiology NAS, Kyïv, Ukraine i.popovych@biph.kiev.ua
}

\begin{abstract}
Background. Previously we have been shown that between parameters of GDV and principal neuroendocrine factors of adaptation exist strong canonical correlation. In the next study, we detected very strong $(\mathrm{R}=0,994)$ integral canonical correlation between the parameters of GDV and Immunity. This study, conducted in the same contingent, will analyze the relationships between GDV parameters, on the one hand, and Phagocytosis and Leukocytogram parameters, on the other. Material and Methods. We observed twice ten women and ten men aged 33-76 years without clinical diagnose. In the morning in basal conditions at first registered kirlianogram by the method of GDV by the device "GDV Chamber" ("Biotechprogress", SPb, RF). Than we counted up the Leukocytogram and determined Interleukin-1 serum level. Results processed by method of canonical analysis, using the software package "Statistica 5.5". Results. According to the value of the canonical correlation coefficient R with GDV parameters, the components of the Leukocytogram are arranged in this order: proportion of monocytes $(0,769)$ and eosinophils $(0,703)$, entropy of Leukocytogram $(0,636)$, total leukocytes level $(0,558)$, proportion of lymphocytes $(0,492)$, stub neutrophils $(0,374)$ and polymorphonuclear neutrophils $(0,307)$. Coefficient of canonical correlation between parameters of GDV, on the one hand, and, on the other hand, Leukocytogram, makes 0,904; Leukocytary Strain\&Adaptation Indices-1 - 0,756; Leukocytary Strain\&Adaptation Indices-2 - 0,783; Interleukin-1 - 0,798. Conclusion. The above data, taken together with the previous ones, state that between parameters of Neuroendocrine-Immune complex and GDV exist strong canonical correlation suggesting suitability of the latter method.
\end{abstract}

Key words: Gas Discharge Visualization, Leukocytogram, Interleukin-1, Relationships. 


\section{INTRODUCTION}

We have been shown that exist strong canonical correlation between parameters of GDV and principal neuroendocrine factors of adaptation [1] as well as parameters of immunity [3] and phagocytosis [4]. This study, conducted in the same contingent, will analyze the relationships between GDV parameters, on the one hand, and the leukocytogram parameters, on the other.

\section{MATERIAL AND METHODS}

The object of observation were 20 volunteers: ten women and ten men aged 33-76 years without clinical diagnose but with dysfunction of neuro-endocrine-immune complex and dysmetabolism.

In the morning we registered the kirlianogram by the method of GDV by the device of "GDV Chamber" ("Biotechprogress", SPb, RF). The first base parameter of GDV is Area of gas discharge image (GDI) in Right, Frontal and Left projections registered both with and without polyethylene filter. The second base parameter is a coefficient of Shape. The third base parameter of GDI is Entropy. Program estimates also Energy and Asymmetry of virtual Chakras [11-13].

In portion of the capillary blood we counted up Leukocytogram (LCG) (Eosinophils, Stub and Segmentonucleary Neutrophils, Lymphocytes and Monocytes) and calculated its Entropy (h) using IL Popovych's [18,20] formula, which is based on classical CE Shannon's formula [23]:

$\mathrm{hLCG}=-\left[\right.$ Lymph $\bullet \log _{2}$ Lymph + Mon $\bullet \log _{2}$ Mon+Eos $\bullet \log _{2}$ Eos $+S N N \bullet \log _{2} S N N+$ StubN $\bullet \log _{2}$ StubN $] / \log _{2} 5$

We determined also the level of Interleukin-1 (ELISA, analyzer "RT-2100C", USA, reagents from "Vector-Best", RF) [15].

Every day four people were tested. A week later, all the tests were repeated.

Results processed by methods of correlation and canonical analyses, using the software package "Statistica 5.5".

\section{RESULTS AND DISCUSSION}

The percentage of monocytes in the Leukocytogram was most closely related to GDV parameters, which is quite expected given the role of monocytes in immunity as an antigenpresenting cells and macrophages. It is noteworthy that all seven Chakras were involved in the downregulation of the level of monocytes in the blood, and to approximately the same extent, judging by the correlation coefficients (Table 1). 
Table 1. Regression Summary for Dependent Variable: Monocyte proportion $\mathrm{R}=0,769 ; \mathrm{R}^{2}=0,592 ;$ Adjusted $\mathrm{R}^{2}=0,411 ; \mathrm{F}_{(12)}=3,27 ; \mathrm{p}=0,005 ; \mathrm{SE}: 1,5 \%$

\begin{tabular}{|l|l|l|l|l|l|l|l|}
\hline \multicolumn{2}{|l|}{} & Beta & $\begin{array}{l}\text { St. Err. } \\
\text { of Beta }\end{array}$ & B & $\begin{array}{l}\text { St. Err. } \\
\text { of B }\end{array}$ & $\mathrm{t}_{(27)}$ & $\begin{array}{l}\text { p- } \\
\text { level }\end{array}$ \\
\hline & r & & Intercpt & $-1,263$ & 8,037 &,- 16 &, 876 \\
\hline Ch4E f & $-0,46$ &,- 392 &, 211 & $-3,465$ & 1,866 & $-1,86$ &, 074 \\
\hline Ch6E f & $-0,45$ & $-1,419$ &, 472 & $-10,542$ & 3,506 & $-3,01$ &, 006 \\
\hline Ch1E f & $-0,44$ &,- 296 &, 241 & $-2,542$ & 2,062 & $-1,23$ &, 228 \\
\hline Ch7E & $-0,43$ &, 508 &, 482 & 4,128 & 3,913 & 1,05 &, 301 \\
\hline Ch2E & $-0,42$ & $-1,005$ &, 705 & $-6,205$ & 4,352 & $-1,43$ &, 165 \\
\hline Ch2E f & $-0,42$ &,- 487 &, 286 & $-4,876$ & 2,862 & $-1,70$ &, 100 \\
\hline Ch3E & $-0,36$ &,- 367 &, 329 & $-2,231$ & 1,998 & $-1,12$ &, 274 \\
\hline Ch5E f & $-0,32$ & 1,654 &, 549 & 11,605 & 3,852 & 3,01 &, 006 \\
\hline Shape F f & 0,45 &,- 426 &, 291 &,- 453 &, 309 & $-1,47$ &, 154 \\
\hline Shape L & 0,36 &, 598 &, 430 &, 274 &, 197 & 1,39 &, 176 \\
\hline Shape F & 0,34 & $-1,605$ &, 780 &,- 593 &, 288 & $-2,06$ &, 049 \\
\hline Entropy F & 0,34 &, 436 &, 177 & 5,381 & 2,192 & 2,46 &, 021 \\
\hline
\end{tabular}

It seems that the level of monocytes is downregulated by the fourth Chakra (associated with thymus) and the third Chakra (associated with spleen) directly and by others through hormones and nerve structures. In particular, due to hormones of adrenal (first Chakra), testes/ovaries (second Chakra), thyroid and parathyroid (fifth Chakra), pituitary and pineal (sixth Chakra) glands as well as vagus nerve, inferior and superior cervical ganglion and celiac plexus (fifth, fourth, sixth and third Chakras) [6,22], which innervate the thymus and spleen [24-26].

According to KJ Tracey's [26] conception of immunological homunculus the CNSs structures that are projected onto certain EEG loci are responsible for certain immune functions. On the other hand, believe that sixth Chakra is associated with left and lower brain, and the seventh Chakra with right and upper brain [6].

Taken together, all Chakras determine the level of monocytes by 59,2\% (Fig. 1).

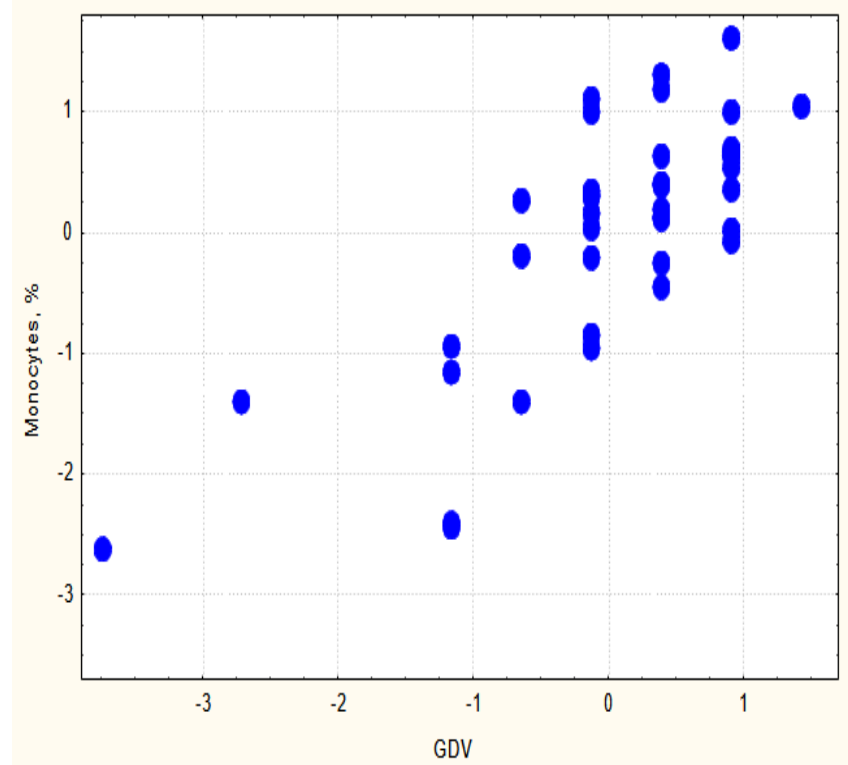

$\mathrm{R}=0,769 ; \mathrm{R}^{2}=0,592 ; \chi_{(12)}^{2}=28,7 ; p=0,004 ; \Lambda$ Prime $=0,408$

Fig. 1. Scatterplot of canonical correlation between GDV parameters (X-line) and the Monocytes level (Y-line) 
The level in the blood of eosinophils is regulated by the chakras less (Table 2 and Fig. 2).

Table 2. Regression Summary for Dependent Variable: Eosinophils proportion

$\mathrm{R}=0,703 ; \mathrm{R}^{2}=0,494 ;$ Adjusted $\mathrm{R}^{2}=0,436 ; \mathrm{F}_{(4,4)}=8,53 ; \mathrm{p}=0,0001 ; \mathrm{SE}: 1,7 \%$

\begin{tabular}{|l|l|l|l|l|l|l|l|}
\hline \multicolumn{2}{|l|}{} & Beta & $\begin{array}{l}\text { St. Err. } \\
\text { of Beta }\end{array}$ & B & $\begin{array}{l}\text { St. Err. } \\
\text { of B }\end{array}$ & $\mathrm{t}_{(35)}$ & $\begin{array}{l}\text { p- } \\
\text { level }\end{array}$ \\
\hline & r & & Intercpt & 51,2 & 25,8 & 1,99 &, 055 \\
\hline Ch6A & 0,50 &, 447 &, 126 & 5,167 & 1,457 & 3,55 &, 001 \\
\hline Ch4E & 0,33 &, 407 &, 122 & 3,793 & 1,143 & 3,32 &, 002 \\
\hline Ch2A f & $-0,29$ &,- 243 &, 122 & $-2,262$ & 1,131 & $-2,00$ &, 053 \\
\hline Symmetry f & $-0,27$ &,- 239 &, 127 &,- 518 &, 276 & $-1,88$ &, 069 \\
\hline
\end{tabular}

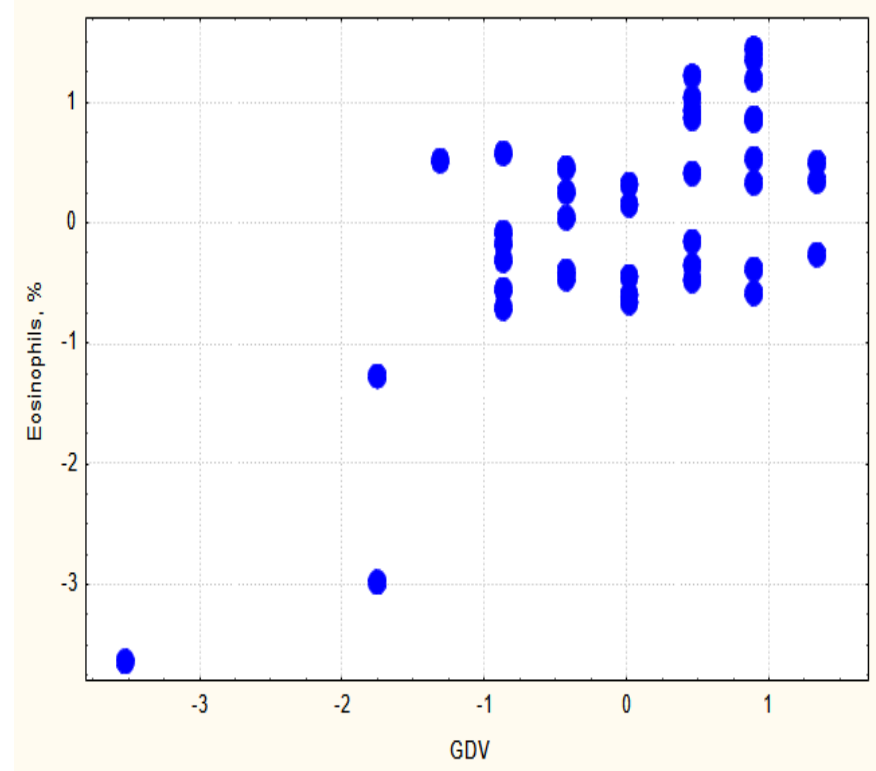

$\mathrm{R}=0,703 ; \mathrm{R}^{2}=0,494 ; \chi^{2}{ }_{(4)}=24,5 ; p<10^{-4} ; \Lambda$ Prime $=0,506$

Fig. 2. Scatterplot of canonical correlation between GDV parameters (X-line) and the Eosinophils level (Y-line)

The level of lymphocytes in the blood is even weaker, but statistically significantly related to the chakras (Table 3).

Table 3. Regression Summary for Dependent Variable: Lymphocytes proportion $\mathrm{R}=0,492 ; \mathrm{R}^{2}=0,242$; Adjusted $\mathrm{R}^{2}=0,155 ; \mathrm{F}_{(4,4)}=2,79 ; \mathrm{p}=0,041 ; \mathrm{SE}: 3,8 \%$

\begin{tabular}{|l|l|l|l|l|l|l|l|}
\hline \multicolumn{2}{|l|}{} & Beta & $\begin{array}{l}\text { St. Err. } \\
\text { of Beta }\end{array}$ & B & $\begin{array}{l}\text { St. Err. } \\
\text { of B }\end{array}$ & $t_{(35)}$ & $\begin{array}{l}\text { p- } \\
\text { level }\end{array}$ \\
\hline & r & & Intercpt & 28,7 &, 647 & 44,3 & $10^{-6}$ \\
\hline Ch1A & $-0,29$ &,- 225 &, 151 & $-4,120$ & 2,768 & $-1,49$ &, 146 \\
\hline Ch6A & $-0,27$ &,- 210 &, 149 & $-4,436$ & 3,158 & $-1,40$ &, 169 \\
\hline Ch1A f & 0,26 &, 268 &, 147 & 5,991 & 3,291 & 1,82 &, 077 \\
\hline Ch3A f & 0,25 &, 195 &, 151 & 3,442 & 2,661 & 1,29 &, 204 \\
\hline
\end{tabular}

In contrast, the associations of both neutrophil populations with GDV parameters were insignificant (Tables 4 and 5). 
Table 4. Regression Summary for Dependent Variable: Stub Neutrophils proportion $\mathrm{R}=0,374 ; \mathrm{R}^{2}=0,140 ;$ Adjusted $\mathrm{R}^{2}=0,093 ; \mathrm{F}_{(2,4)}=3,01 ; \mathrm{p}=0,061 ; \mathrm{SE}: 1,1 \%$

\begin{tabular}{|l|l|l|l|l|l|l|l|}
\hline \multicolumn{2}{|l|}{} & Beta & $\begin{array}{l}\text { St. Err. } \\
\text { of Beta }\end{array}$ & B & $\begin{array}{l}\text { St. Err. } \\
\text { of B }\end{array}$ & $\mathrm{t}_{(37)}$ & $\begin{array}{l}\text { p- } \\
\text { level }\end{array}$ \\
\hline & r & & Intercpt & 3,39 &, 247 & 13,7 & $10^{-6}$ \\
\hline Ch1E & $-0,34$ &,- 214 &, 195 &,- 764 &, 697 & $-1,10$ &, 280 \\
\hline Ch4E & $-0,33$ &,- 201 &, 195 &,- 916 &, 888 & $-1,03$ &, 309 \\
\hline
\end{tabular}

Table 5. Regression Summary for Dependent Variable: PMN Neutrophils proportion $\mathrm{R}=0,307 ; \mathrm{R}^{2}=0,094 ;$ Adjusted $\mathrm{R}^{2}=0,070 ; \mathrm{F}_{(1,4)}=3,94 ; \mathrm{p}=0,054 ; \mathrm{SE}: 4,4 \%$

\begin{tabular}{|l|l|l|l|l|l|l|l|}
\hline \multicolumn{2}{|l|}{} & Beta & $\begin{array}{l}\text { St. Err. } \\
\text { of Beta }\end{array}$ & B & $\begin{array}{l}\text { St. Err. } \\
\text { of B }\end{array}$ & $\mathrm{t}_{(38)}$ & $\begin{array}{l}\text { p- } \\
\text { level }\end{array}$ \\
\hline & r & & Intercpt & 71,9 & 6,25 & 11,5 & $10^{-6}$ \\
\hline Shape F f & $-0,31$ &,- 307 &, 154 &,- 757 &, 381 & $-1,99$ &, 054 \\
\hline
\end{tabular}

Interestingly, the Entropy of the Leukocytogram as an information parameter [] also correlates with the information parameters of GDV, in particular its entropy (Table 6).

Table 6. Regression Summary for Dependent Variable: Entropy of Leukocytogram $\mathrm{R}=0,636 ; \mathrm{R}^{2}=0,404 ;$ Adjusted $\mathrm{R}^{2}=0,274 ; \mathrm{F}_{(7,3)}=3,10 ; \mathrm{p}=0,013 ; \mathrm{SE}: 0,035$

\begin{tabular}{|l|l|l|l|l|l|l|l|}
\hline \multicolumn{2}{|l|}{} & Beta & $\begin{array}{l}\text { St. Err. } \\
\text { of Beta }\end{array}$ & B & $\begin{array}{l}\text { St. Err. } \\
\text { of B }\end{array}$ & $\mathrm{t}_{(32)}$ & $\begin{array}{l}\text { p- } \\
\text { level }\end{array}$ \\
\hline & r & & Intercpt &,- 233852 &, 370506 &,- 63 &, 532 \\
\hline Shape F f & 0,41 &, 489 &, 232 &, 011023 &, 005233 & 2,11 &, 043 \\
\hline Ch6A & 0,36 &, 344 &, 145 &, 072039 &, 030356 & 2,37 &, 024 \\
\hline Activation Coef & 0,29 &, 369 &, 228 &, 014629 &, 009039 & 1,62 &, 115 \\
\hline Entropy F & 0,26 &, 266 &, 175 &, 069710 &, 045830 & 1,52 &, 138 \\
\hline Ch3E & $-0,38$ &,- 315 &, 238 &,- 040605 &, 030730 & $-1,32$ &, 196 \\
\hline Area L & $-0,29$ &, 441 &, 279 &, 000006 &, 000004 & 1,58 &, 124 \\
\hline Symmetry & $-0,26$ &, 338 &, 246 &, 002812 &, 002050 & 1,37 &, 180 \\
\hline
\end{tabular}

The last smear of the picture is Table 7 on the total content of leukocytes in the blood.

Table 7. Regression Summary for Dependent Variable: Leukocytes level $\mathrm{R}=0,559 ; \mathrm{R}^{2}=0,312 ;$ Adjusted $\mathrm{R}^{2}=0,255 ; \mathrm{F}_{(3,4)}=5,44 ; \mathrm{p}=0,003 ; \mathrm{SE}: 0,63 \mathrm{G} / \mathrm{L}$

\begin{tabular}{|l|l|l|l|l|l|l|l|}
\hline \multicolumn{2}{|l|}{} & Beta & $\begin{array}{l}\text { St. Err. } \\
\text { of Beta }\end{array}$ & B & $\begin{array}{l}\text { St. Err. } \\
\text { of B }\end{array}$ & $\mathrm{t}_{(36)}$ & $\begin{array}{l}\text { p- } \\
\text { level }\end{array}$ \\
\hline & r & & Intercpt & 4,942 &, 426 & 11,6 & $10^{-6}$ \\
\hline Ch1A & $-0,43$ &,- 378 &, 145 & $-1,199$ &, 461 & $-2,60$ &, 014 \\
\hline Ch1A f & 0,31 &, 319 &, 138 & 1,233 &, 535 & 2,30 &, 027 \\
\hline Shape R & 0,28 &, 179 &, 146 &, 033 &, 027 & 1,23 &, 227 \\
\hline
\end{tabular}

Taken together, the parameters of the Leukocytogram are determined by the parameters of GDV by $81,8 \%$ (Table 8 and Fig. 3 ). 
Table 8. Factor Structure of GDV and Leukocytogram's Canonical Roots

\begin{tabular}{|c|c|}
\hline Right set & $\mathrm{R}$ \\
\hline Ch6A & ,752 \\
\hline Ch5A &, 538 \\
\hline Ch1A &, 460 \\
\hline Shape F f & ,273 \\
\hline Entropy F & ,252 \\
\hline Shape L & ,233 \\
\hline Shape F & ,206 \\
\hline Shape R & ,081 \\
\hline Ch7E & ,071 \\
\hline Ch6E f &, 065 \\
\hline Ch1A f &,- 270 \\
\hline Ch1E f &,- 260 \\
\hline Ch1E &,- 248 \\
\hline Ch4E f &,- 205 \\
\hline Ch2E f &,- 204 \\
\hline Ch3E &,- 180 \\
\hline Ch4E &,- 110 \\
\hline Ch2E &,- 057 \\
\hline Left set & $\mathrm{R}$ \\
\hline Eosinophils & ,510 \\
\hline Entropy LCG &, 488 \\
\hline Monocytes & ,373 \\
\hline Stub Neutrophils & , 162 \\
\hline Lymphocytes &,- 461 \\
\hline Leukocytes &,- 396 \\
\hline
\end{tabular}

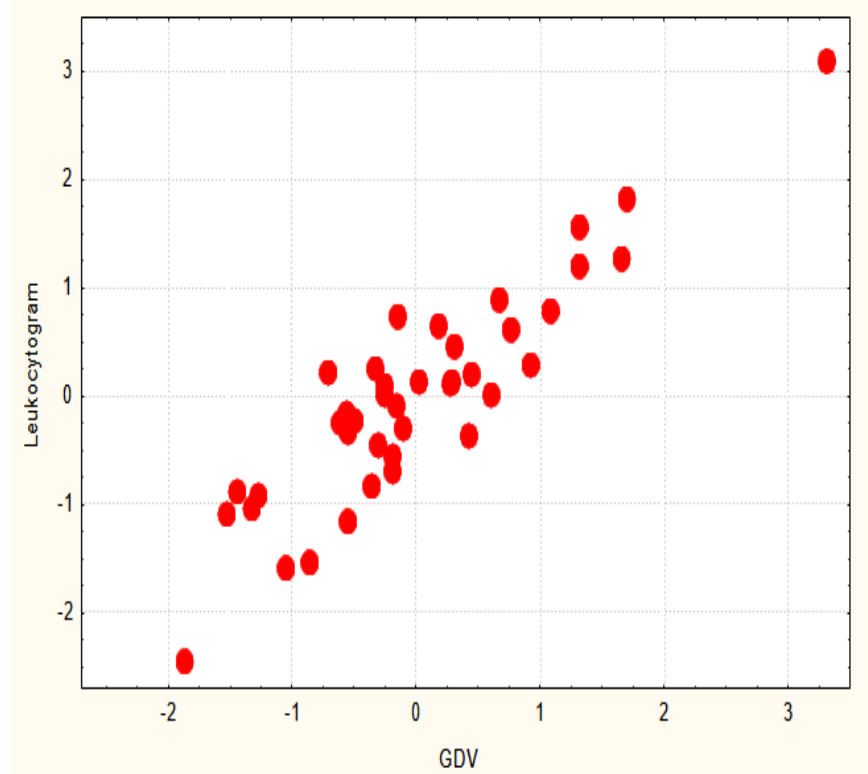

$R=0,904 ; R^{2}=0,818 ; \chi_{(108)}^{2}=138 ; p=0,027 ; \Lambda$ Prime $=0,005$

Fig. 3. Scatterplot of canonical correlation between parameters of the GDV (X-line) and the Leukocytogram (Y-line) 
Based on the elements of the Leukocytogram we calculated its Strain Index as well as Adaptation Index by IL Popovych, which reflect the levels and ratios of the major hormones of adaptation $[5,8,9,17]$.

Strain Index-1 $=\left[(\mathrm{Eo} / 3,5-1)^{2}+(\mathrm{SN} / 3,5-1)^{2}+(\mathrm{Mon} / 5,5-1)^{2}+(\mathrm{Leu} / 6-1)^{2}\right] / 4$

Strain Index-2 $=\left[(\mathrm{Eo} / 2,75-1)^{2}+(\mathrm{SN} / 4,25-1)^{2}+(\mathrm{Mon} / 6-1)^{2}+(\mathrm{Leu} / 5-1)^{2}\right] / 4$

As expected, the links between Leukocytary Indices and Chakras, which represent the endocrine glands that secrete adaptive hormones, have been found. It is stated that the second version of the indices is somewhat more informative than the first (Tables 9 and 10 and Figs. 4 and 5).

Table 9. Regression Summary for Dependent Variable: Popovych's Strain Index-1 $\mathrm{R}=0,740 ; \mathrm{R}^{2}=0,548$; Adjusted $\mathrm{R}^{2}=0,481 ; \mathrm{F}_{(5,3)}=8,2 ; \mathrm{p}<10^{-4} ; \mathrm{SE}: 0,10$

\begin{tabular}{|l|l|l|l|l|l|l|l|}
\hline \multicolumn{2}{|l|}{} & Beta & $\begin{array}{l}\text { St. Err. } \\
\text { of Beta }\end{array}$ & B & $\begin{array}{l}\text { St. Err. } \\
\text { of B }\end{array}$ & $\mathrm{t}_{(34)}$ & $\begin{array}{l}\text { p- } \\
\text { level }\end{array}$ \\
\hline & r & & Intercpt & 0,238 & 0,038 & 6,21 & $10^{-6}$ \\
\hline Ch6A & 0,63 & 0,420 & 0,133 & 0,293 & 0,093 & 3,16 & 0,003 \\
\hline Ch6E & 0,46 & 1,512 & 0,477 & 0,716 & 0,226 & 3,17 & 0,003 \\
\hline Ch5E & 0,35 & $-0,977$ & 0,407 & $-0,444$ & 0,185 & $-2,40$ & 0,022 \\
\hline Ch6E f & 0,20 & $-0,256$ & 0,193 & $-0,135$ & 0,101 & $-1,33$ & 0,193 \\
\hline Ch7E & 0,11 & $-0,144$ & 0,142 & $-0,083$ & 0,081 & $-1,02$ & 0,315 \\
\hline
\end{tabular}

Table 10. Regression Summary for Dependent Variable: Popovych's Adaptation Index-1

$\mathrm{R}=0,497 ; \mathrm{R}^{2}=0,247 ;$ Adjusted $\mathrm{R}^{2}=0,184 ; \mathrm{F}_{(3,4)}=3,94 ; \mathrm{p}=0,016$; SE: 0,40

\begin{tabular}{|l|l|l|l|l|l|l|l|}
\hline \multicolumn{2}{|l|}{} & Beta & $\begin{array}{l}\text { St. Err. } \\
\text { of Beta }\end{array}$ & B & $\begin{array}{l}\text { St. Err. } \\
\text { of B }\end{array}$ & $\mathrm{t}_{(36)}$ & $\begin{array}{l}\text { p- } \\
\text { level }\end{array}$ \\
\hline & r & & Intercpt & $-0,842$ & 1,584 & $-0,53$ & 0,598 \\
\hline Ch6A & $-0,33$ & $-0,355$ & 0,147 & $-0,796$ & 0,329 & $-2,42$ & 0,021 \\
\hline Entropy R f & 0,29 & 0,211 & 0,149 & 0,611 & 0,430 & 1,42 & 0,164 \\
\hline Ch1A & 0,26 & 0,266 & 0,150 & 0,516 & 0,291 & 1,77 & 0,085 \\
\hline
\end{tabular}

Table 11. Factor Structure of GDV and Strain\&Adaptation Indices-1 Canonical Roots

\begin{tabular}{|l|l|}
\hline Right set & R \\
\hline Ch6A & $-\mathbf{0 , 8 3 2}$ \\
\hline Ch6E & $-\mathbf{0 , 6 2 8}$ \\
\hline Ch5E & $-\mathbf{0 , 4 8 6}$ \\
\hline Ch6E f & $\mathbf{- 0 , 2 8 0}$ \\
\hline Ch7E & $\mathbf{- 0 , 1 4 7}$ \\
\hline Entropy R f & $\mathbf{0 , 1 5 3}$ \\
\hline Ch1A & $\mathbf{0 , 0 8 2}$ \\
\hline Left set & R \\
\hline Strain Index-1 & $\mathbf{- 0 , 9 9 7}$ \\
\hline Adaptation Index-1 & $\mathbf{0 , 5 4 1}$ \\
\hline
\end{tabular}




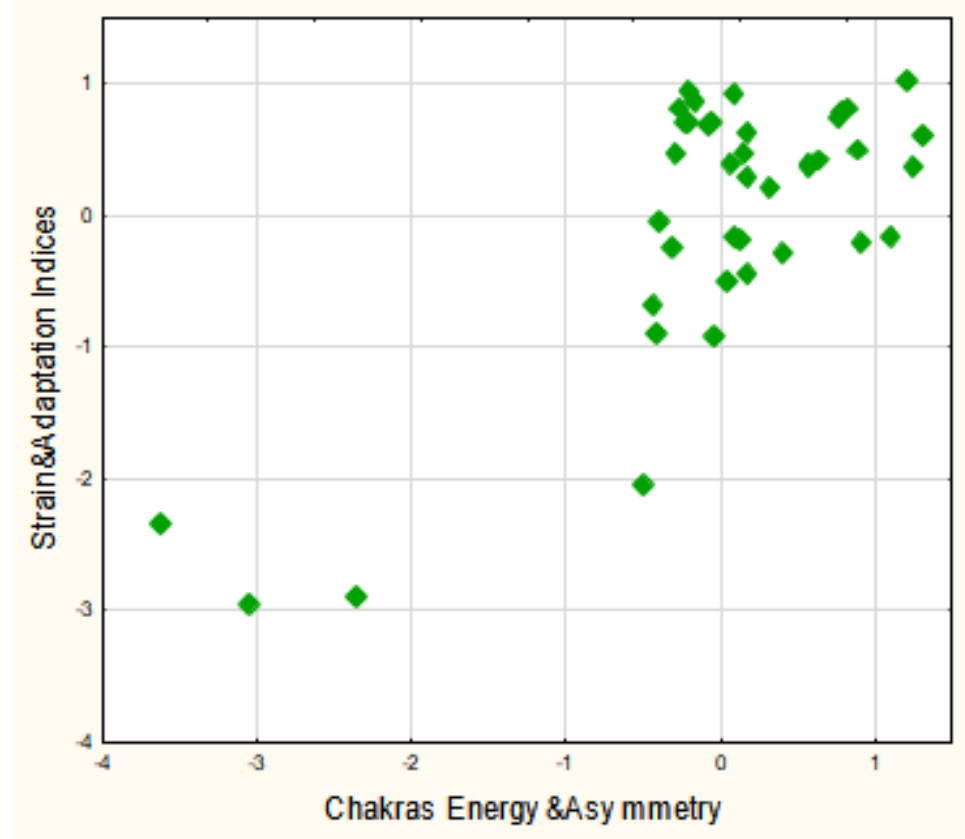

$\mathbf{R}=0,756 ; \mathbf{R}^{2}=0,572 ; \chi_{(14)}^{2}=37 ; p=0,0007 ; \Lambda$ Prime $=0,336$

Fig. 4. Scatterplot of canonical correlation between parameters of the GDV (X-line) and the Leukocytary Indices-1 (Y-line)

Table 12. Regression Summary for Dependent Variable: Popovych's Strain Index-2 $\mathrm{R}=0,781 ; \mathrm{R}^{2}=0,611 ;$ Adjusted $\mathrm{R}^{2}=0,553 ; \mathrm{F}_{(5,3)}=10,7 ; \mathrm{p}<10^{-5} ; \mathrm{SE}: 0,186$

\begin{tabular}{|l|l|l|l|l|l|l|l|}
\hline \multicolumn{2}{|l|}{} & Beta & $\begin{array}{l}\text { St. Err. } \\
\text { of Beta }\end{array}$ & B & $\begin{array}{l}\text { St. Err. } \\
\text { of B }\end{array}$ & $\mathrm{t}_{(34)}$ & $\begin{array}{l}\text { p- } \\
\text { level }\end{array}$ \\
\hline & r & & Intercpt & 0,387 & 0,113 & 3,41 & 0,002 \\
\hline Ch6A & 0,59 & 0,447 & 0,129 & 0,627 & 0,180 & 3,48 & 0,001 \\
\hline Ch6E & 0,52 & 1,540 & 0,427 & 1,466 & 0,406 & 3,61 & 0,001 \\
\hline Ch5E & 0,37 & $-1,242$ & 0,388 & $-1,135$ & 0,354 & $-3,20$ & 0,003 \\
\hline Ch4E & 0,26 & 0,208 & 0,183 & 0,235 & 0,207 & 1,14 & 0,263 \\
\hline Ch7E & 0,21 & $-0,212$ & 0,172 & $-0,244$ & 0,198 & $-1,23$ & 0,226 \\
\hline
\end{tabular}

Table 13. Regression Summary for Dependent Variable: Popovych's Adaptation Index-2

$\mathrm{R}=0,465 ; \mathrm{R}^{2}=0,216 ;$ Adjusted $\mathrm{R}^{2}=0,174 ; \mathrm{F}_{(2,4)}=5,11 ; \mathrm{p}=0,011 ; \mathrm{SE}: 0,29$

\begin{tabular}{|l|l|l|l|l|l|l|l|}
\hline \multicolumn{2}{|l|}{} & Beta & $\begin{array}{l}\text { St. Err. } \\
\text { of Beta }\end{array}$ & B & $\begin{array}{l}\text { St. Err. } \\
\text { of B }\end{array}$ & $\mathrm{t}_{(37)}$ & $\begin{array}{l}\text { p- } \\
\text { level }\end{array}$ \\
\hline & r & & Intercpt & 0,964 & 0,046 & 20,8 & $10^{-6}$ \\
\hline Ch5A & $-0,37$ & $-0,430$ & 0,149 & $-0,652$ & 0,225 & $-2,89$ & 0,006 \\
\hline Ch5E & 0,20 & 0,286 & 0,149 & 0,301 & 0,156 & 1,93 & 0,062 \\
\hline
\end{tabular}


Table 14. Factor Structure of GDV and Strain\&Adaptation Indices-2 Canonical Roots

\begin{tabular}{|l|l|}
\hline Right set & R \\
\hline Ch6A & $-\mathbf{0 , 7 5 4}$ \\
\hline Ch6E & $-\mathbf{0 , 6 8 1}$ \\
\hline Ch5A & $-\mathbf{0 , 5 8 7}$ \\
\hline Ch5E & $-\mathbf{0 , 4 9 5}$ \\
\hline Ch4E & $-\mathbf{0 , 3 2 7}$ \\
\hline Ch7E & $\mathbf{- 0 , 2 7 7}$ \\
\hline Left set & R \\
\hline Strain Index-2 & $\mathbf{- 0 , 9 9 8}$ \\
\hline Adaptation Index-2 & $\mathbf{0 , 1 9 1}$ \\
\hline
\end{tabular}

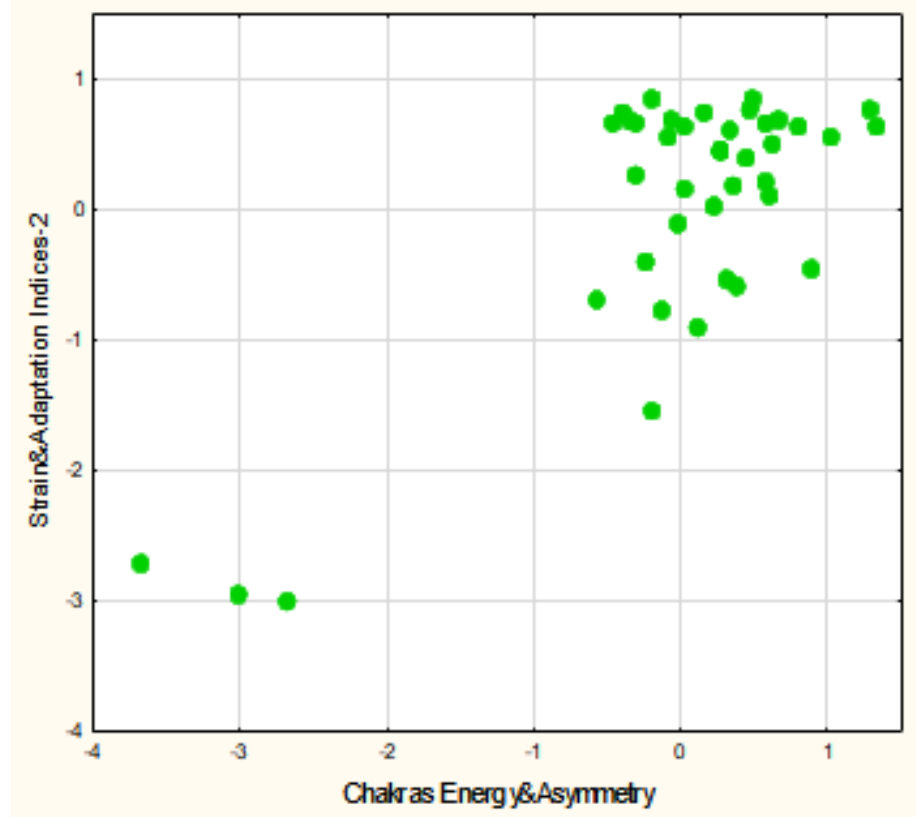

$\mathrm{R}=0,783 ; \mathrm{R}^{2}=0,613 ; \chi_{(12)}^{2}=44 ; \mathrm{p}<10^{-4} ; \Lambda$ Prime $=0,280$

Fig. 5. Scatterplot of canonical correlation between parameters of the GDV (X-line) and the Leukocytary Indices-2 (Y-line)

Since leukocytes secrete cytokines [27], it is appropriate to analyze the relationship with GDV parameters of Interleukin-1 plasma levels. It was found that it is determined by the Entropy of GDV in the Left projection and the parameters of the five Chakras by $63,8 \%$ (Table 15 and Fig. 6). 
Table 15. Regression Summary for Dependent Variable: IL-1

$\mathrm{R}=0,798 ; \mathrm{R}^{2}=0,638 ;$ Adjusted $\mathrm{R}^{2}=0,477 ; \mathrm{F}_{(12,3)}=3,96 ; \mathrm{p}=0,0015 ; \mathrm{SE}: 0,81 \mathrm{ng} / \mathrm{L}$

\begin{tabular}{|l|l|l|l|l|l|l|l|}
\hline \multicolumn{2}{|l|}{} & Beta & $\begin{array}{l}\text { St. Err. } \\
\text { of Beta }\end{array}$ & B & $\begin{array}{l}\text { St. Err. } \\
\text { of B }\end{array}$ & $\mathbf{t}_{(27)}$ & $\begin{array}{l}\text { p- } \\
\text { level }\end{array}$ \\
\hline & r & & Intercpt & $-20,9$ & 5,17 & $-4,04$ &, 0004 \\
\hline Entropy L & 0,40 &, 533 &, 145 & 3,586 &, 973 & 3,69 &, 0010 \\
\hline Entropy L f & 0,30 &, 540 &, 170 & 3,374 & 1,062 & 3,18 &, 0037 \\
\hline Ch6E f & 0,31 & 1,079 &, 343 & 4,590 & 1,460 & 3,14 &, 0040 \\
\hline Ch6E & 0,27 &,- 867 &, 355 & $-3,324$ & 1,359 & $-2,45$ &, 0213 \\
\hline Ch1E & 0,24 &, 747 &, 349 & 2,676 & 1,252 & 2,14 &, 0417 \\
\hline Ch3A & 0,23 &, 441 &, 156 & 1,562 &, 554 & 2,82 &, 0089 \\
\hline Ch6A f & 0,23 &,- 660 &, 235 & $-2,560$ &, 910 & $-2,81$ &, 0090 \\
\hline Ch4A & 0,22 &, 440 &, 144 & 1,537 &, 501 & 3,07 &, 0049 \\
\hline Ch1E f & 0,21 &,- 743 &, 281 & $-3,649$ & 1,381 & $-2,64$ &, 0135 \\
\hline Ch4E f & 0,18 &,- 757 &, 308 & $-3,834$ & 1,557 & $-2,46$ &, 0205 \\
\hline Ch4E & 0,17 &, 908 &, 315 & 4,142 & 1,436 & 2,88 &, 0076 \\
\hline Ch7A & $-0,19$ &,- 373 &, 149 & $-1,430$ &, 572 & $-2,50$ &, 0187 \\
\hline
\end{tabular}

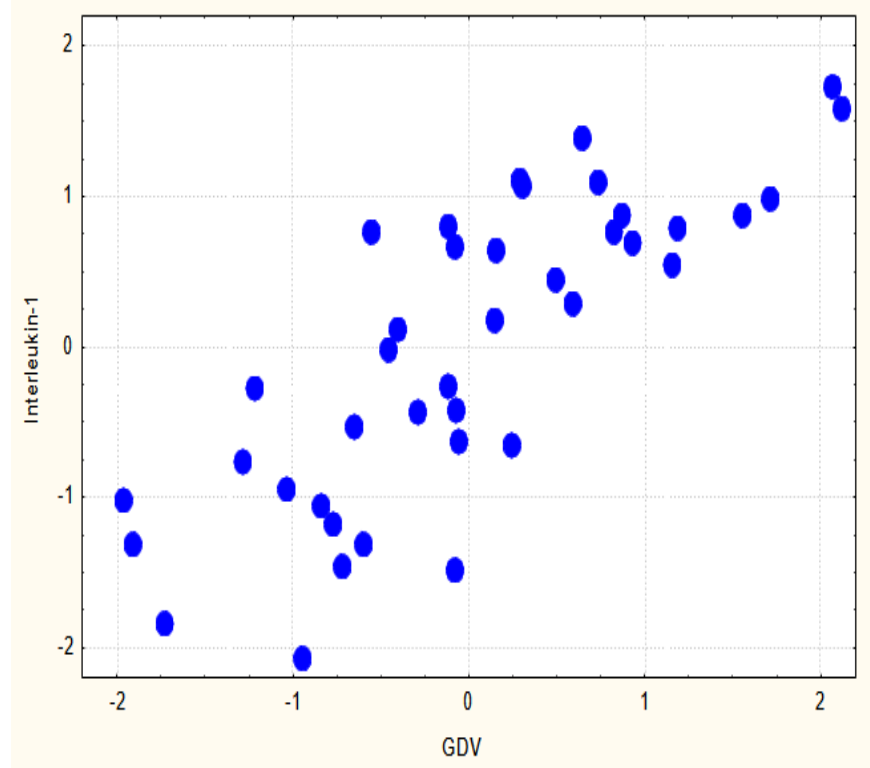

$\mathrm{R}=0,798 ; \mathrm{R}^{2}=0,638 ; \chi_{(12)}^{2}=32,5 ; \mathrm{p}=0,0012 ; \Lambda$ Prime $=0,362$

Fig. 6. Scatterplot of canonical correlation between GDV parameters (X-line) and the Interleukin-1 level (Y-line)

The next article in this project will analyze the relationships between GDV and EEG parameters with a detailed discussion.

\section{ACKNOWLEDGMENT}

We express sincere gratitude to administration JSC "Truskavets'kurort" for help in carrying out immune analyzes. Special thanks to the volunteers.

\section{ACCORDANCE TO ETHICS STANDARDS}


Tests in volunteers are conducted in accordance with positions of Helsinki Declaration 1975, revised and complemented in 2002, and directive of National Committee on ethics of scientific researches. During realization of tests from all participants the informed consent is got and used all measures for providing of anonymity of participants.

\section{REFERENCES}

1. Babelyuk VE, Gozhenko AI, Dubkova GI, Babelyuk NV, Zukow W, Kovbasnyuk MM, Popovych IL. Causal relationships between the parameters of gas discharge visualization and principal neuroendocrine factors of adaptation. Journal of Physical Education and Sport. 2017; 17(2): 624-637.

2. Babelyuk VYe, Popadynets' OO, Dubkova GI, Zukow W, Muszkieta R, Gozhenko OA, Popovych IL. Entropy of gas-discharge image correlates with the entropies of EEG, immunocytogram and leukocytogram but not HRV. Pedagogy and Psychology of Sport. 2020; 6(2): 30-39.

3. Babelyuk VYe, Gozhenko AI, Dubkova GI, Zukow W, Hubyts'kyi VY, Ruzhylo SV, Fedyayeva SI, Kovalchuk HY, Popovych IL. Causal relationships between the parameters of gas discharge visualization and immunity. Pedagogy and Psychology of Sport. 2021; 7(1): 115-134.

4. Babelyuk VY, GozhenkoAI, Dubkova GI, Babelyuk NV, Zukow W, Kindzer BM, Kovbasnyuk MM, Popovych IL. Causal relationships between the parameters of gas discharge visualization and phagocytosis. Journal of Education, Health and Sport. 2021; 11(6): 268-276.

5. Barylyak LG., Malyuchkova RV, Tolstanov OB, Tymochko OB, Hryvnak RF, Uhryn MR. Comparative estimation of informativeness of leukocytary index of adaptation by Garkavi and by Popovych. Medical Hydrology and Rehabilitation. 2013; 11(1): 5-20.

6. Chase CR. The Geometry of Emotions: Using Chakra Acupuncture and 5-Phase Theory to Describe Personality Archetypes for Clinical Use. Med Acupunct. 2018; 30(4): 167-178.

7. Chebanenko OI, Flyunt IS, Tserkovnyuk RG, Popovych IL, Alyeksyeyev OI, Kyjenko VM. Rehabilitation of Protective and Adaptive Systems in the Truskavets' spa [in Ukrainian]. Kyiv. UNESCO-SOCIO; 2004: 448.

8. Garkavi LKh, Kvakina EB, Kuz'menko TS. Antistressory Reactions and Activating Therapy [in Russian]. Moskva. Imedis; 1998: 654.

9. Garkavi LKh, Romasyuk SI, Barantsev FG, Kuz'menko TS, Otkidach SA, Tatkov OV, Barantseva LP. Activation therapy in the complex of the sanatorium-resort stage of rehabilitation of patients with diseases of internal organs [in Russian]. Sochi; 2000: 94.

10. Gozhenko AI, Zukow W, Polovynko IS, Zajats LM, Yanchij RI, Portnichenko VI, Popovych IL. Individual Immune Responses to Chronic Stress and their Neuro-Endocrine Accompaniment. RSW. UMK. Radom. Torun; 2019: 200.

11. Korotkov KG. Basics GDV Bioelectrography [in Russian]. SPb. SPbGITMO(TU); 2001: 360.

12. Korotkov KG. Principles of Analysis in GDV Bioelectrography [in Russian]. SPb. Renome; 2007: 286.

13. Korotkov KG. Energy Fields Electrophotonic Analysis in Humans and Nature. Second updated edition. Translated from Russian by the author. Edited by Berney Williams and Lutz Rabe. 2014: 233.

14. Kul'chyns'kyi AB, Kyjenko VM, Zukow W, Popovych IL. Causal neuro-immune relationships at patients with chronic pyelonephritis and cholecystitis. Correlations between parameters EEG, HRV and white blood cell count. Open Medicine. 2017; 12(1): 201-213.

15. Lapovets' LYe, Lutsyk BD. Laboratory Immunology [in Ukrainian]. Kyïv. 2004: 173.

16. Marques-Deak A, Cizza G, Sternberg E. Brain-immune interactions and disease susceptibility. Mol Psychiatry. 2005; 10(3): 239-250.

17. Petsyukh SV, Petsyukh MS, Kovbasnyuk MM, Barylyak LG, Zukow W. Relationships between Popovych's Adaptation Index and parameters of ongoiging HRV and EEG in patients with 
chronic pyelonephrite and cholecystite in remission. Journal of Education, Health and Sport. 2016; 6(2): 99-110.

18. Popadynets' OO, Gozhenko AI, Zukow W, Popovych IL. Relationships between the entropies of EEG, HRV, immunocytogram and leukocytogram. Journal of Education, Health and Sport. 2019; 9(5): 651-666.

19. Popovych IL (editor). General Adaptation Reactions and Body's Resistance in Liquidators of the Chernobyl Accident [in Ukrainian]. Kyiv. Computerpress; 2000: 117.

20. Popovych IL. Information effects of bioactive water Naftyssya in rats: modulation entropic, prevention desynchronizing and limitation of disharmonizing actions water immersion stress for information components of neuro-endocrine-immune system and metabolism, which correlates with gastroprotective effect [in Ukrainian]. Medical Hydrology and Rehabilitation. 2007; 5(3): 50-70.

21. Popovych IL, Gozhenko AI, Zukow W, Polovynko IS. Variety of Immune Responses to Chronic Stress and their Neuro-Endocrine Accompaniment. Scholars' Press. Riga; 2020: 172.

22. Puchko LG. Multidimensional Medicine. Systen of Self-diagnosis and Self-healing of Human [in Russian]. 10th ed., rev. and ext. Moskva. ANS; 2004: 432.

23. Shannon CE. Works on the theory of informatics and cybernetics [transl. from English to Russian]. Moskva. Inostrannaya literatura; 1963: 329.

24. Sternberg EM. Neural regulation of innate immunity: a coordinated nonspecific host response to pathogens. Nat Rev Immunol. 2006; 6(4): 318-328.

25. Thayer JF, Sternberg EM. Neural aspects of immunomodulation: Focus on the vagus nerve. Brain Behav Immun. 2010; 24(8): 1223-1228.

26. Tracey KJ. Physiology and immunology of the cholinergic antiinflammatory pathway. $\mathrm{J}$ Clin Invest. 2007; 117(2): 289-296.

27. Uchakin PN, Uchakina ON, Tobin BV, Ershov FI. Neuroendocrine immunomodulation [in Russian]. Vestnik Ross AMN. 2007; 9: 26-32. 